\title{
CORRELATION BETWEEN THEORY OF CRIMINAL LIABILITY AND CRIMINAL PUNISHMENT TOWARD CORPORATION IN INDONESIA CRIMINAL JUSTICE PRACTICE
}

\author{
Septa Candra \\ Faculty of Law Universitas Muhammadiyah Jakarta \\ Doctoral Candidate at Post-Graduate Studies in law Universitas Padjadjaran Bandung \\ E-mail: septa.candra85@gmail.com
}

\begin{abstract}
The question of the correlation between theory of criminal liability and criminal punishment on criminal acts committed corporation is important to investigate in order to provide justification for the criminal prosecution of corporations. How a mistake should be constructed from a corporation associated with the theory of corporate criminal liability. As a consequence of the improper condition on the corporate views of whether the corporation has made a criminal offense can be avoided as part of discretion in running the business. If these obligations are not met, the corporation can be condemned for committing crime. The practice of criminal justice to the determination of criminal liability for corporations is not fully in accordance with the theory of corporate criminal liability. In fact, the court decision does not yet reflect a consistent correlation between the theory of criminal liability and criminal punishment on criminal acts of the corporation.
\end{abstract}

Keywords: criminal liability, corporate, criminal justice

\begin{abstract}
Abstrak
Persoalan tentang korelasi antara teori pertanggungjawaban pidana dan penjatuhan pidana terhadap tindak pidana yang dilakukan korporasi, menjadi penting untuk dikaji guna dapat memberikan justifikasi terhadap pemidanaan korporasi. Bagaimana harus dikonstruksikan kesalahan dari suatu korporasi dihubungkan dengan teori pertanggungjawaban pidana korporasi. Sebagai konsekuensinya syarat kesalahan pada korporasi dilihat dari apakah korporasi tersebut telah menjadikan dapat dihindari-nya tindak pidana sebagai bagian kebijakannya dalam menjalankan usaha. Apabila kewajiban ini ti-dak dipenuhi, maka korporasi itu dapat dicela jika karenanya terjadi suatu tindak pidana. Praktik peradilan pidana terhadap penentuan pertanggungjawaban pidana korporasi selama ini belum sepenuhnya sesuai dengan teori pertanggungjawaban pidana korporasi. Dalam kenyataannya putusan pengadilan belum mencerminkan suatu korelasi yang sejalan antara teori pertanggungjawaban pidana dan penjatuhan pidana terhadap tindak pidana korporasi.
\end{abstract}

Kata kunci: pertanggungjawaban pidana, korporasi, peradilan pidana

Introduction

As a role of corporation in various field plays greater, particularly economy and the tendency of corporate committed crimes in achieving its goals, then there has been a shift in the view that the corporation is also the subject of criminal law in addition to human. ${ }^{1}$ The

Ridwan Rangkuti, “Pertanggungjawaban Korporasi Terhadap Tindak Pidana Lingkungan Hidup Menurut UndangUndang Nomor 23 Tahun 1997", Jurnal Justitia, Vol. 1 No. 03, August 2014, Padangsidampuan: Faculty of Law Universitas Muhammadiyah Tapanuli Selatan, page 260 261. main purpose of a corporation by principles of economics is to seek maximum profit with the minimum capital issued. In order to make a profit, corporate often conducts practices irregularities that apparently violate law. ${ }^{2}$

The corporation is an association of people and good fortune of a legal entity or not; the Association may implement the rights as or-

\footnotetext{
Henry Donald Lbn. Toruan, "Pertanggungjawaban Pidana Korupsi Korporasi”, Jurnal Rechtsvinding, Vol. 3 No. 3, December 2014, Jakarta: Badan Pembinaan Hukum Na-sional, page 404.
} 
dinary people (individuals) and can be accounted for. Nevertheless, the corporations should act through the intermediary of ordinary people for and on corporate accountability. ${ }^{3}$ Yet, until now there is still a variation on the process of enforcing the law against corporations in various countries, even Germany does not recognize the existence of criminal liability that applies to corporations because they assume only people who can be burdened for the accountability of criminal liability. ${ }^{4}$

The recognition of corporations as subjects of criminal law means corporations can be accounted for. It also means that both academics and practitioners, a specific crime called corporate crime is considered as a crime where the perpetrator (corporation) can be accounted for in the criminal law. The corporate criminal liability system adopted by the criminal justice system is aimed to determine the corporation as a creator and is responsible with regard to the functional perpetrators based on the doctrine of identification theory. This doctrine considers that the actions and misdeeds of senior officials are seen as an act and an inner attitude of the company. ${ }^{5}$

The more contemporary views found conceptual flaws in the concept of corporate criminal liability oriented to the individuality of the managers who manage the corporation. According to this view, the corporation is considered as an independent entity and has completely different characteristics from the human family. The significant role of corporations in social life is the justification for the corporation to be the subject of offense regardless of manager's existence. The fact that the corporation has complexity and different characteristics with hu-

3 M Haryanto, "Pertanggungjawaban Pidana Korporasi dan Individualisasi pidana", Jurnal Ilmu Hukum Refleksi Hukum, October 2012, Yogyakarta: Faculty of Law Universitas Kristen Satya Wacana, page 194.

4 H Santhos Wachjoe P, "Pertanggungjawaban Pidana Terhadap Korporasi”, Jurnal Hukum dan Peradilan, Vol. 5 No. 2, July 2016, Jakarta: Pusat Penelitian dan Pengembangan Hukum dan Peradilan Mahkamah Agung, page 163.

5 Zulkarnain, “Kebijakan Hukum Pidana Tentang Kejahatan Korporasi dan Sistem Pertanggungjawaban Pidananya Dalam Penanggulangan Kejahatan Korporasi", Jurnal Law Review, Vol. XI No. 3, March 2012, Tangerang: Faculty of Law Universitas Pelita Harapan, page 347-348. mans requires criminal law to seek new alternatives of a form of accountability in order to understand the corporation structural and functional complexity. Viewed from individualistic tendency, the complexity of the corporation is not understood comprehensively. On that basis, criminal law experts provide a new alternative for corporate responsibility which focuses on accountability, functional and corporate structure. This is done because structurally and functionally the corporation has its own personal actions and misdeeds that allow corporations to realize in surveillance, standard operating procedures (SOP) and corporate policy. Characteristics of the corporation as a legal entity as well as a legal subject considers not only an artificial legal subjects, but also as bearers of rights and duties before the law re-garded and treated as a human which is the subject of natural law. Needless to say then if the corporation is also legally defensible included in the criminal law course by taking into account characteristics of the corporation. It should be noted since if the characteristics were ignored, there will be chaos in the law itself as a system. ${ }^{6}$

Related to criminal responsibility, it cannot separated from crime, although the sense of criminal offenses does not include issue of criminal responsibility. Rather, a criminal act only refers to prohibited acts, to be convicted a criminal liability occurred, and beforehand their criminal responsibility should be clear who will be accounted for. This issue concerns the subject of criminal offenses which are generally formulated by lawmakers for any criminal offense. $^{7}$

Mardjono Reksodiputro, related to the acceptance of the corporation as a subject of criminal law, said that in this case there is an increase of understanding of who the perpetrators of criminal acts (dader). The problem that

6 Adriano, "Karakteristik Pertanggungjawaban Pidana Korporasi”, Jurnal Hukum dan Peradilan, Vol. 5 No. 1, March 2016, Jakarta: Pusat Penelitian dan Pengembangan Hukum dan Peradilan Mahkamah Agung, page 106.

7 Husni, "Kebijakan Formulasi Pertanggungjawaban Pidana Terhadap Korporasi”, Jurnal Ilmu Hukum REUSAM, Vol. IV No. 1, May 2015, Aceh: Faculty of Law Universitas Malikussaleh, page 82. 
immediately arises has relation with corporation criminal liability. The main principle of criminal responsibility is there should be a fault (schuld) on the perpetrators; how a fault can be constructed from a corporation. The common theory nowadays splits between the actions against the law (criminal law) with its responsibilities under criminal law. Tort is committed by a corporation. This has now been made possible. Yet, what about accountability? We can imagine that there are elements of errors (either intentional or negligence)in a corporation. If the perpetrator is human, the error is associated with criticism (verwijbaarheid/blameworthiness) as it relates to the perpetrator mentality or psyche. What if the actors are not human but corporation? ${ }^{8}$

In this paper the authors put forward the concept of corporate criminal liability and also a correlation between criminal liability and criminal punishment of the offenses corporation in criminal justice practices to suit the characteristics of the corporation. Furthermore, this paper present how to determine the fault on the corporation and causes punishment in accordance with the fault.

\section{Discussion}

The principle of "no punishment without guilt" in the criminal law is typically used in the sense that there is no crime without subjective fault or no fault can be reproached. However in criminal law people cannot speak about faults without any improper actions. To put clearer, the principle of no punishment without guilt as an inappropriate act objectively, perceived as despicable act. It said the guilty principle is a fundamental principle in criminal law, consequently, it is so pervasive and echoes in almost criminal law theories. Then the question is how the influence of the guilty principles when a corporation is prosecuted for a criminal offense. Since a legal entity does not have a human soul (psyche menselijke) and emotional elements (de

Mardjono, 1994, Reksodiputro, Kemajuan Pembangunan Ekonomi dan Kejahatan, Kumpulan Karangan Buku Kesatu, Jakarta: Pusat Pelayanan Keadilan dan Pengabdian Hukum UI, page 101-102. psychische bestanddelen) so it can be said to have an error. ${ }^{9}$

Suprapto as stated by Muladi and Dwidja said that the corporation may have errors when intentional or omissions contained on those who become its tools. The mistake was not individual because it is about the body as a collective (kolektiveit) which can be attributed to its leaders. Besides, it is reasonable to assume the legal entity has errors and therefore must bear the wealth he received illicit profits. ${ }^{10}$ Then, Muladi expressed his opinion that "the principle of no punishment without fault" remains in force, as long as it is carried out by the board. Otherwise, if a crime is actually committed by a corporation (maker fictitious), the "principle of no punishment without fault" does not apply. ${ }^{11}$

In the process, theoretically (according to the doctrine) the legal entity as the subject of criminal offenses can be criminally accountable as follows: first, shall be liable to the corporation (legal entity) itself; second, apply to those who give orders or act as leaders in the act a criminal offense (board); third, apply both to corporations and those who gave orders or act as a leader in the act of committing a criminal act of the (board) or both, are legal entities and officials. ${ }^{12}$

It is interesting to be study deeper about how exactly the subject corporation may be the subject to criminal law. Indonesian criminal law applies the principles of error which is the basis for criminal liability that apply to offenders who violate the provisions of the criminal law. In order to convict the perpetrator of the offense and to prove the elements of disapproval ac-

9 Erni Mustikasari, “Penerapan Pertanggungjawaban Pidana Korporasi dalam Praktek Penuntutan Perkara di Pengadilan", Jurnal Bina Adhyaksa, Vol. 5 No. 2, March 2015, Jakarta: Pusat Penelitian dan Pengembangan Kejaksaan Agung, page 160 .

10 Muladi dan Dwidja Priyatno, 2010, Pertanggungjawaban Pidana Korporasi, Jakarta: Kencana Prenada Media Group, hlm 47.

11 Ibid., page 106

12 Septya Sri Rezeki, "Pertanggungjawaban Korporasi Terhadap Penerapan Prinsip Strict Liability Dalam Kasus Kerusakan Lingkungan Hidup", Jurnal Hukum Pidana Islam Al-Jinayah, Vol. 1 No. 1, June 2015, Surabaya: Faculty of Sharia and Law UIN Sunan Ampel, page 258. 
tions, within perpetrators must be no element of fault. ${ }^{13}$

Identification of the corporation as a legal subject in a criminal act is carried out by considering if the traffic corporations in society determines the state of the forbidden. Mardjono Reksodiputro sees this as a shift maker criminal offense of 'fysieke dader' leading to functionele dader'. ${ }^{14}$ Thus, the theory of functional maker of Roling as the first filter to determine whether an offense is basically done by the corporation or it is solely as a one's act who happened to have a position in a corporation. In this case, the corporation may be treated as criminals when the forbidden acts carried out in the framework of the implementation of tasks and/ or achievement of the goals of the corporation. ${ }^{15}$

In addition, corporation can only act through caretaker-managers. Thus, the external er-ror condition to the corporation depends on the relationship between corporation with 'the actors'. Crimes committed by corporation always an inclusion may be liable. In this case, the position of the corporation has always been part of the inclusion of such crime.

Corporation is perceived committing crime when: it occurs in common association inclusion (non vicarious liability crime); and in terms of vicarious liability crime. The first is commonly committed by corporate leaders dealing with determining corporate policy. Thus, if the culprit is the "director and managers who represent the directing mind and will of the company and control what it does", ${ }^{16}$ then corporation position as one who commits crime can be seen from the common inclusion relationship. In this case the corporation was in a relationship with its material creator, as referred to

13 Amirullah, "Korporasi Dalam Perspektif Subyek Hukum Pidana", Jurnal Hukum dan Perundangan Islam Al-Daulah, Vol. 2 No. 2, October 2012, Surabaya: Program Studi Siyasah Jinayah Faculty of Sharia and Law UIN Sunan Ampel, page 142.

14 Mardjono Reksodiputro, 1997, Bunga Rampai Permasalahan dalam Sistem Peradilan Pidana, Jakarta: Pusat Pelayanan Keadilan dan Pengabdian Hukum, hlm 138.

15 Ibid., page 260.

16 Muladi, Demokratisasi, 2002, Hak Asasi Manusia dan Reformasi Hukum di Indonesia, Jakarta: The Habibie Centre, page 162 .
Article 55 of the Criminal Code. In contrast, the latter may take place if the material creator is subordinate or executive personnel, or an employee acting within the framework of its authority and on behalf of the corporation. ${ }^{17}$

In terms of determining corporation criminal responsibility is different from person. On the subject of human law requirements (internal) error is determined from the manufacturer's psychological state, namely the inner normal circumstances, different from the terms error (internal) on corporations. In corporate terms of errors seen if the corporation has made a criminal offense can be avoided as part of discretion in running the business. It is a corporate obligation to avoid potential crimes. If these obligations are not met, the corporation can be censured for violating law.

Actually there are three conditions that must be met for their corporate responsibility, namely: first, the agent commits a crime; second, the crimes committed are still in his workplace circumstances; and third, it was carried out in order to benefit the corpora-tion. ${ }^{18}$ Furthermore, as a corporation regarded as criminal, it can be accounted for some legislations. Related to criminal liability corporation, some doctrines are provided as follows: the doctrine of identification (Identification), the doctrine of accountability replacement (vicarious liability), and the doctrine of strict liability by law (strict liability). ${ }^{19}$

First, the doctrine of identification. Accountability is known in Anglo-Saxon countries such as the UK. The concept of accountability is known as "direct corporate criminal liability". The principle of "mens rea" is not ruled out, ac-

17 Ibid, page 161.

18 Levina Yustitianingtyas, "Pertanggungjawaban Pidana oleh Korporasi Dalam Tindakan Pelanggaran HAM di Indonesia”, Jurnal Ilmu Hukum Novelty, Vol. 7 No. 1, February 2016, Yogyakarta: Fakultas Hukum Universitas Ahmad Dahlan, page 29.

19 Rony Saputra, "Pertanggungjawaban Pidana Korporasi Dalam Tindak Pidana Korupsi”, Jurnal Cita Hukum, Vol. II No. 2, December 2015, Jakarta: Faculty of Sharia and Law Universitas Islam Negeri Syarif Hidayatullah, page 280; Laila Mulasari, "Ajaran Pertanggungjawaban Pidana Korporasi Dalam Kebijakan Hukum Pidana Di Bidang Mayantara", Hukum Dan Dinamika Masyarakat, Vol. 9 No. 2, April 2012, Semarang: Faculty of Law Universitas Tujuhbelas Agustus Semarang, page 119. 
cording to this doctrine, the inner attitude or actions of senior corporate officials who have the directing mind can be considered a corporate attitude. This means that the inner attitude can be identified as a corporation, the corporation could be held accountable directly. Second, The doctrine of replacement liability (vicarious liability). Accountability replacement is someone without personal fault liability yet responsible for others' fault. This doctrine states that a person can be held accountable for others' actions mistakes. Thus, the employer is the primary responsibility of the actions of the laborers who carry out acts within the scope of his duties. Such accountability is almost entirely applied to the criminal offense explicitly prescribed in the legislation. That is, not all criminal acts can be performed vicarious. ${ }^{20}$ Third, the doctrine of strict liability by law (strict liability). This doctrine is the principle of accountability absolute answer without having to prove the existence of an element of criminal's fault. This means that the author has been able to be convicted if he has violated law. However, applying the principle of strict liability and actions not only endanger the people but also difficult to prove. Endangering the public does not only have a serious criminal offense but also include the "regulatory offenses" such as traffic violations, environment, food, drinks and medicines that do not meet health requirements. ${ }^{21}$ However, the fault remains with the implementation of the principle of strict liability but the burden of proof is shifted from the prosecution to the person suspected of committing a prohibited act. ${ }^{22}$

Terms of errors on corporations in the literature refer to the terms of power (machtsve-

20 Kristian, "Urgensi Pertanggungjawaban Pidana Korporasi”, Jurnal Hukum dan Pembangunan, Year 44 No. 4, October-December 2013, Jakarta: Faculty of Law Universitas Indonesia, page 609

21 Septa Candra, "Pembaharuan Hukum Pidana: Konsep Pertanggungjawaban Pidana Dalam Hukum Pidana Nasional Yang Akan Datang", Jurnal Cita Hukum, Vol. I No. 1, Juni 2013, Jakarta: Faculty of Sharia and Law Universitas Islam Negeri Syarif Hidayatullah, hlm 46.

22 Ridho Kurniawan and Siti Nurul Intan Sari D, "Pertang gungjawaban Pidana Korporasi Berdasarkan Asas Strict Liability", Jurnal Yuridis, Vol. 1 Number 2, December 2014, Jakarta: Faculty of Law Universitas Pembangunan Nasional Veteran Jakarta, page 164. reiste). Terms of power can only be fulfilled if it proves the legal entity in reality is less/null and/pursue a policy or precaution in order to prevent forbidden perpetration. Thus, a corporation can be held accountable for a crime if the obligation to avoid as far as the criminal case happen is not fulfilled. Muladi argues as follows:

"Terms powers include: authority to regulate/control and/or govern the parties in fact commit the forbidden act; is able to exercise its powers and basically able to take decisions on the relevant issues; and able to pursue policies or security measures in order to prevent illicit omissions." 23

Observed closely, it can be underlined that not all instances cited in the above opinion can be said as a condition of power. Following the theory of separation between criminal conduct and criminal accountability, the 'authority to regulate/control and/or govern the parties in fact commit the forbidden act', is not part of the error condition on corporations. Nonetheless, regarding to the criteria that determine whether a criminal offense can be said to have been committed by a corporation particularly to distinguish when an offense committed by a corporation and when it is said as agent acts alone. Thus, it is an external fault condition. Authority to regulate/control and/or govern the parties who in fact commit a crime concerns with the corporation as participants of a crime and material maker.

Meanwhile, to implement its powers and basically to take decisions on the relevant issues of such offenses are overview on the state of the corporate voluntary. Thus, it is more likely to determine the guilt of the corporation and not the conditions. Only with respect will it be able to pursue policies or security measures in order to prevent the perpetration of prohibited acts', which is a term of mistake on corporations. This is a necessary condition to declare a corporation accountable in criminal law and possible to be imposed punishment.

23 Muladi, op.cit., page 160 . 
The conception of criminal liability against the corporation, as noted above, is not fully understood and followed in Indonesian criminal justice practices, especially by the judges in determining the criminal liability of corporations. For example, in Decision Number 131/ Pid.B/2013/PN.MBO PT. Kallista Alam (as a defendant) was found guilty after it had been proven to commit the crime of the Environment. In the verdict, the judges convict PT. Kalista Alam to pay a fine of Rp.3.000.000.000,- (three billion rupiah). Indicted act against PT. Kallista is to do the burning land as stipulated in Article 108 in conjunction with Article 69 paragraph (1) letter h Law Number 32 Year 2009 on the Prevention and Management of the Environment (Law of PPLH). The Judges considered the case as follows:

Considering that the Law PPLH in Article 2 concerning the principle stipulates the principle of prudence, and thus careless attitude towards environmental management of plantation PT. Kallista Alam, employees and staff defendant were not able to extinguish the fire; it must be declared opening a $\mathrm{n}$ land has been carried out by burning.

The authors believe that the judges' consideration in determining the criminal offenses committed by the corporation based on the principles that underlie the establishment of a law is certainly not right. The more general/ fundamental principle does not specify an action which can be regarded as a criminal offense. Regarding the principle of law, it should only be used as a general view in running or enforcing a provision of the law. Thus, it believes that the judges had failed to connect the acts that occur whether the acts of the corporation or even an act of its officials in this regard Ir. Khamidin Yoesoef (Land Development Manager). On the other hand, the court's decision can be seen to have followed the view of the separation of a crime and criminal responsibility (external fault condition) where the authority to regulate/ control and/or govern the parties who in fact commit a crime concerns with the corporation as participants of a crime and material maker. In other parts, the Judges also stated:
Considering the facts revealed at the hearing as described above, the defendant of fires on land is owned by PT. Kallisa Alam where the witness Ir. Khamidin Yoesoef as manager for its non-realization of maximum supervision in the garden area though it revealed the accused PT. Kallisa Alam which had issued letter No. 03.02/ KA/1999 dated March 9, 1999, concerning the danger of fire. The witness Ir. Khamidin Yoesoef conveyed to witness Elvis as the contractor to be careful in dry season.

Considering that witness testimony Elvis who did the contract with the witness Ir. Khamidin Yoesoef for land clearing 300 hectares for and on behalf of the defendant PT. Kallista Alam, in one item agreement Elvis witness testified that the company and the contractor has implemented a witness Zero Burning or clearing land without burning but they burned peat instead.

Considering that the criminal law in any known their intent to understand the theory of "so be it" in Kauf nauhmen theories or "op de Koop toe nemen theories" i.e. the state of mind of the perpetrator and his actions are as follows: (a) due to the fact it was not desirable, even to hate or fear about the possible result of it, (b), but even though he does not want it he should dare take a risk in certain circumstances.

The authors believe that in Judges' judgment to determine the guilt corporations is not in line with the "requisite authority" that the terms (internal) corporate error; it appears from the fact the corporation has taken decisions on the relevant issues of crime that occurs. In this case the corporation in the contract terms have implemented land clearing without burning (zero burning). Despite the fact that peat is still burning, is not a form of deliberate action or omission of the corporation. In this case the corporation has also been working on policy or security measures in order to prevent the perpetration of acts prohibited. The court's decision has not shown a correlation or relationship between criminal liability and criminal punishment against corporations based on the theory of corporate criminal liability. 


\section{Conclusion}

At the end of this article, the authors would like to say that the issue of corporate criminal liability remains a problem both theoretically and judicial practice on criminal acts committed by the corporation. To put it specific, it concerns with determining the correlation or relationship between criminal liability and criminal punishment on criminal acts of the corporation. Criminal justice practices indicate lack of a common criteria to determine whether a criminal offense can be said to have been committed by a corporation or the managers (agents) solely.

In terms of determining criminal responsibility of the corporation, it is different from person. In corporate, terms of errors seen whether the corporation has made a criminal offense can be avoided as part of discretion in running the business. If these obligations are not met, then the corporation can not reproach hence there is a criminal. It is also a warning for the judges to be able to provide a justification for corporate punishment, especially for judges prudence more to convict the right to the corporation by virtue of his guilt, to avoid corporation or innocent managers being convicted or convicted exceed their mistakes.

\section{References}

Adriano. "Karakteristik Pertanggungjawaban Pidana Korporasi". Jurnal Hukum dan Peradilan. Vol. 5 No. 1. March 2016. Jakarta: Pusat Penelitian dan Pengembangan Hukum dan Peradilan Mahkamah Agung;

Amirullah. "Korporasi Dalam Perspektif Subyek Hukum Pidana". Jurnal Hukum dan Perundangan Islam Al-Daulah. Vol. 2 No. 2. October 2012. Surabaya: Program Studi Siyasah Jinayah Fakultas Syari'ah dan Hukum UIN Sunan Ampel;

Candra, Septa. "Pembaharuan Hukum Pidana: Konsep Pertanggungjawaban Pidana Dalam Hukum Pidana Nasional Yang Akan Datang”. Jurnal Cita Hukum. Vol. I No. 1. June 2013. Jakarta: Faculty of Sharia and Law Universitas Islam Negeri Syarif Hidayatullah;

Haryanto, M. "Pertanggungjawaban Pidana Korporasi dan Individualisasi pidana". Jurnal
Ilmu Hukum Refleksi Hukum. October 2012. Yogyakarta: Faculty of Law Universitas Kristen Satya Wacana;

Husni. "Kebijakan Formulasi Pertanggungjawaban Pidana Terhadap Korporasi". Jurnal Ilmu Hukum REUSAM. Vol. IV No. 1. May 2015. Aceh: Faculty of Law Universitas Malikussaleh;

Kristian. "Urgensi Pertanggungjawaban Pidana Korporasi”. Jurnal Hukum dan Pembangunan. Year 44 No. 4. October-December 2013. Jakarta: Faculty of Law Universitas Indonesia;

Kurniawan, Ridho dan Siti Nurul Intan Sari D. "Pertanggungjawaban Pidana Korporasi Berdasarkan Asas Strict Liability". Jurnal Yuridis. Vol. 1 No. 2. December 2014. Jakarta: Faculty of Law Universitas Pembangunan Nasional Veteran Jakarta;

Mardjono Reksodiputro. Kemajuan Pembangunan Ekonomi dan Kejahatan. Kumpulan Karangan Buku Kesatu. 1994. Jakarta: Pusat Pelayanan Keadilan dan Pengabdian Hukum UI;

Muladi dan Dwidja Priyatno. 2010. Pertanggungjawaban Pidana Korporasi. Jakarta: Kencana Prenada Media Group;

Muladi. 2002. Demokratisasi Hak Asasi Manusia dan Reformasi Hukum di Indonesia. Jakarta: The Habibie Centre;

Mulasari, Laila. "Ajaran Pertanggungjawaban Pidana Korporasi Dalam Kebijakan Hukum Pidana Di Bidang Mayantara". Hukum Dan Dinamika Masyarakat. Vol. 9 No. 2. April 2012. Semarang: Faculty of Law Universitas Tujuhbelas Agustus Semarang;

Mustikasari, Erni. "Penerapan Pertanggungjawaban Pidana Korporasi dalam Praktek Penuntutan Perkara di Pengadilan". Jurnal Bina Adhyaksa. Vol. 5 No. 2. March 2015. Jakarta: Pusat Penelitian dan Pengembangan Kejaksaaan Agung;

$\mathrm{P}, \mathrm{H}$. Santhos Wachjoe. "Pertanggungjawaban Pidana Terhadap Korporasi". Jurnal Hukum dan Peradilan. Vol. 5 No. 2. July 2016. Jakarta: Pusat Penelitian dan Pengembangan Hukum dan Peradilan Mahkamah Agung;

Rangkuti, Ridwan. "Pertanggungjawaban Korporasi Terhadap Tindak Pidana Lingkungan Hidup Menurut Undang-Undang Nomor 23 Tahun 1997". Jurnal Justitia. Vol. 1 No. 03. August 2014. Padangsidampuan: Fac- 
ulty of Law Universitas Muhammadiyah Tapanuli Selatan;

Reksodiputro, Mardjono. 1997. Bunga Rampai Permasalahan dalam Sistem Peradilan Pidana. Jakarta: Pusat Pelayanan Keadilan dan Pengabdian Hukum;

Rezeki, Septya Sri. "Pertanggungjawaban Korporasi Terhadap Penerapan Prinsip Strict Liability Dalam Kasus Kerusakan Lingkungan Hidup". Jurnal Hukum Pidana Islam AlJinayah. Vol. 1 No. 1. June 2015. Surabaya: Faculty of Sharia and Law UIN Sunan Ampel;

Saputra, Rony. "Pertanggungjawaban Pidana Korporasi Dalam Tindak Pidana Korupsi”. Jurnal Cita Hukum. Vol. II No. 2. December 2015. Jakarta: Faculty of Sharia and Law Universitas Islam Negeri Syarif Hidayatullah;
Toruan, Henry Donald Lbn. "Pertanggungjawaban Pidana Korupsi Korporasi". Jurnal Rechtsvinding. Vol. 3 No. 3. December 2014. Jakarta: Badan Pembinaan Hukum Nasional;

Yustitianingtyas, Levina. "Pertanggungjawaban Pidana oleh Korporasi Dalam Tindakan Pelanggaran HAM di Indonesia". Jurnal Ilmu Hukum Novelty. Vol. 7 No. 1. February 2016. Yogyakarta: Faculty of Law Universitas Ahmad Dahlan;

Zulkarnain. "Kebijakan Hukum Pidana Tentang Kejahatan Korporasi dan Sistem Pertanggungjawaban Pidananya Dalam Penanggulangan Kejahatan Korporasi". Jurnal Law Review. Vol. XI No. 3. March 2012. Tangerang: Faculty of Law Universitas Pelita Harapan. 